Myrosław Trofymuk

Lwowski Uniwersytet Narodowy im. Iwana Franki

\title{
Fryderyk Chopin i Łesia Ukrainka. Per me
}

Twórczość Chopina, odkąd sięgam pamięcią, była obecna w moim życiu. Rodzice kochali taniec i muzykę, a w domu jednym z najczęściej wykorzystywanych sprzętów był wiekowy gramofon przeznaczony do odtwarzania starych płyt winylowych, tych obracających się 78 razy na minutę. Między tangami, walcami, muzyką ludową, swingiem i ariami z oper słuchałem utworów fortepianowych, które mnie jako dziecku bardzo się podobały.

Nie wiedziałem wtedy, że to kompozycje Fryderyka Szopena (właśnie tak zręczniej było mi zawsze zapisywać jego nazwisko, jeżeli nie posługiwałem się cyrylicą). Na pewno w płytotece znajdowały się także utwory innych wybitnych mistrzów muzyki fortepianowej, ale pamiętam, że kiedy jako piętnastolatek zapytałem moją siostrę, kto jest autorem słuchanej przez nas melodii, stwierdziła, że to właśnie Chopin. Kończyła wtedy szkołę średnią i pilnie przygotowywała się przed egzaminem wstępnym do konserwatorium. Rzecz jasna, dla mnie była absolutnym autorytetem w dziedzinie muzyki klasycznej. Od wczesnego ranka do późnego wieczora w naszym mieszkaniu wciąż brzmiała muzyka. Siostra umieszczała płytę na talerzu odtwarzacza, a następnie zaczynała grać na pianinie... 
Kiedy się myliła, zaczynała rywalizację z płytą od nowa... Trwało to do momentu, aż kiedyś, bardzo wzruszony kilkudziesięcioma niedokończonymi wykonaniami sonaty Ludwiga van Beethovena (którą znałem już dokładnie na pamięć), wkradłem się cichutko do pokoju siostry w czasie jej krótkiej nieobecności i położyłem na struny pianina mały kocyk. Byłem zaskoczony, gdy wszyscy domownicy radośnie stwierdzili, że to dobre rozwiązanie: możemy obcować z wielkimi dziełami muzyki europejskiej, lecz w trybie rozsądnie ograniczonym. Moja siostra, która - jak przypuszczam też była zadowolona $\mathrm{z}$ tego wynalazku i wiedziała, kto jest jego autorem, nigdy mego sprawstwa nie wyjawiła przed rodziną.

Nie miałem jej za złe tych intensywnych seansów muzycznych, bo przy okazji opowiedziała mi mnóstwo ciekawych i mądrych rzeczy. Zapewne później i tak dowiedziałbym się o jazzie, o muzyce klasycznej i rockowej, ale dzięki siostrze od razu uzyskałem dostęp do wyrafinowanych utworów. Od swoich kolegów miała nowe płyty z całego świata, tydzień lub dwa po ich premierze. To była moja wyższa szkoła estetyczna w dziedzinie muzyki, zwłaszcza klasycznej...

Moje życie w dużej części wypełniała, obok słuchania płyt, lektura utworów literackich w różnych językach. Często zaczynałem czytać książki w oryginale (stron 10 lub 20, w zależności od tego, w jakim stopniu znałem język), a potem te same fragmenty poznawałem w tłumaczeniu na ukraiński. W naszym domowym księgozbiorze znajdowałem mnóstwo oryginałów i tłumaczeń, dzięki którym mogłem porównywać różne brzmienia i treści.

Życie biegło swoim trybem i trwał ten cudowny dla mnie świat wesołych zajęć: badminton, pływanie, jazda na rowerze, bieganie oraz najciekawsze, jak mówiono we Lwowie, „łazanie po stromach”. Nagle czas się zatrzymał, lustro bezgłośnie rozbiło się na kawałki... Zmarł mój dziadek. Miałem wtedy 15 lat.

Dziadek był twórcą naszego wspólnego raju na ziemi. Eden ten mieścił się na skrawku jego dziedzicznej ziemi. Gdy władza chciała mu grunt odebrać, obmyślił sposób, jak do tego nie dopuścić: otóż upaństwowieniu nie podlegały sady, więc obsadził ziemię jabłoniami. Chodziliśmy później między drzewami, dziadek chwytał i przyginał gałęzie, ja smakowałem jabłka. Wspólnie szczepiliśmy jabłonie, a rok lub kilka lat później cieszyliśmy się dojrzewającymi 
na wszczepionych gałązkach owocami. Byłem radośnie oszołomiony tym wybitnym odkryciem, że bardzo proste życie jest dziwne, naprawdę cudowne, choć wiedziałem dobrze, że nie ma nic nadzwyczajnego ani w spożywaniu owoców, ani w nich samych'.

Właśnie z nim, z dziadkiem, a także z ojcem, przeżywaliśmy radosne winobranie. Pierwszy dokręcałem korbę prasy do owoców, potem dziadek, a wreszcie ojciec. Śpiewaliśmy przy tym różne piosenki i pieśni, wesołe i smutne, a wszystko odbywało się pod pogodnym niebem, pod sufitem zaczerwienionych zachodzącym słońcem chmur. Potrzebne były jeszcze czary, wiedza czerpana z tajemniczej recepty i odpowiednio długi czas - dzięki tym czynnikom wyciśnięty z gron sok alchemicznie przemieniał się w wino, sumę dziwnych zapachów i smaków. Stara, zdziczała winorośl rośnie w, teraz już moim, „majątku”, ale regionalne wino nie smakuje już tak, jak kiedyś, i nie wiem, czy zdołam jeszcze w swoim życiu odnaleźć mój własny przepis na wino, prawdziwe wino.

Nowe owoce znalazłem wkrótce po śmierci dziadka. W głębokim kontemplacyjnym skupieniu zacząłem słuchać płytę z Sonatą fortepianowa b-moll op. 35. Znałem ten utwór już od dawna, ale dopiero w tamtej chwili odczułem Chopina per se. Właściwego. Odkryłem nastawienie artysty do życia i ten smutny nastrój, który zapowiada nowy początek, tę nostalgię, dającą impuls do dalszego trwania. A może i zgodę na własne odchodzenie, swoistą próbę sztuki dobrej śmierci, łączącą się ze stworzeniem nowego utworu, nowego świata. Alteram naturam. Tak, miałem wtedy 15 lat...

Następnym okresem zbliżenia z muzyką Chopina był początek znajomości z moją żoną, czas naszej młodości i miłości, na pewno najświetniejszy w naszym życiu. Zakochaliśmy się w sobie bez pamięci, stwarzaliśmy własny świat. Częste wizyty w dobrych kinach i na wystawach znajomych artystów, spektakle w teatrze, koncerty muzyki klasycznej w Filharmonii Lwowskiej oraz w sali koncertowej w kościele pw. św. Marii Magdaleny. Właśnie koncerty chopinowskie najbardziej odpowiadały naszemu nastrojowi i naszym uczuciom. Jeden z moich wierszy z tamtego czasu tak brzmi w oryginale:

1 Nawiązanie do fragmentu piosenki zespołu SBB [2021] pt. Memento z banalnym tryptykiem. 
Щоніч приходиш ти Ао мене

сіАаєш поруч і рука

твоя стирає шрами Аенні

стирає згорблені слова.

Щоніч приходиш ти Ао мене

й, покмавши крила на чоло

нашіптуєш так колисково

ноктюрн Шопена № 2.

A oto przekład:

Co noc przychodzisz do mnie siadasz obok i ręka

twa usuwa blizny dzienne, ścierając zgarbione słowa.

Co noc przychodzisz do mnie i, kładąc skrzydła na czole, szepczesz kołysankę -

Nokturn Chopina nr 2.

Uczestnictwo w koncertach stało się także naszą tradycją rodzinną. Od młodych lat, a właściwie nie - od dzieciństwa chodziliśmy do filharmonii z małym Mirkiem. Pewnego razu zasnął na IX Symfonii d-moll op. 125 Beethovena. Patrzyłem wówczas na jego spokojną twarz z łagodnym uśmiechem i myślałem, jak głęboko przeżywa koncert, taka artystyczna dusza... A on otworzył zdziwione oczy dopiero na finał, dostatecznie głośny.

Mieliśmy w domu różne odtwarzacze, a przez parędziesiąt lat gromadziliśmy nagrania, najpierw ja sam, potem wraz z małżonką, w końcu dołączył również nasz syn. W fonotece znalazły się zapisy muzyki liturgicznej (prawosławne i katolickie, ze szczególnym miejscem dla chorału gregoriańskiego), nagrania folklorystyczne różnych narodowości, rock, jazz, muzyka popularna.

Od pewnego momentu, dokładnie od roku 1993, zaczęliśmy jeździć do Polski, by odbywać staże i stypendia biblioteczne. Najpierw trafiliśmy do Warszawy, a tam bardzo szybko dowiedzieliśmy się o koncertach chopinowskich w Łazienkach. I tak powstała kolejna 
tradycja: gdy ktoś z nas trojga był w Warszawie, choćby przejazdem, zawsze próbował dotrzeć na koncert, bez względu na pogodę.

Kiedyś, już nie pamiętam, w którym to było roku, po upalnym letnim dniu wieczorem lunął deszcz. Syn i ja siedzieliśmy przy samym krańcu stawu, naprzeciw sceny i pomnika. Kiedy deszcz zaczął padać, nikt ze słuchaczy się nie ruszył. Sala pod chmurnym niebem zakwitła różnobarwnymi parasolami, a po ukończeniu programu wyszedł konferansjer i ogłosił, że wykonawca ma zamiar zagrać, zgodnie z pogodą, „deszczowy” utwór Chopina. Dotąd tej muzyki nie znaliśmy, nigdy później nie słyszeliśmy jej w tak wymownych okolicznościach. Wykonanie trwało krótko, a dźwięki Chopina sypały się jak gorące krople na umysł i duszę, zestrajając się z rytmicznym brzmieniem deszczowych kropel, spadających na okrągłe zwierciadło stawu przed nami. Nuty okrągłymi koronami eksplodowały nad powierzchnią wody i to echo, ta rozmowa muzyki i deszczu były po prostu niesamowite...

W mojej rodzinie panował miłosny kult dzieł z różnych sfer sztuki. Jednym z najważniejszych obiektów tego kultu była twórczość wybitnej poetki ukraińskiej Łarysy Petriwny Kosacz, córki wspóltwórczyni ukraińskiego odrodzenia narodowego Ołeny Pcziłky oraz kuzynki słynnego Mychajła Dragomanowa, znanej pod pseudonimem Łesia Ukrainka. Świadectwem tego rodzimego kultu jest także imię mojej siostry Łarysy, skrócone do formy Łesia. Dziwnym zbiegiem okoliczności imię mojej małżonki, Oleksandra, po ukraińsku w zdrobnieniu także brzmi Łesia.

Kiedy już zostałem mniej więcej doświadczonym historykiem literatury, ostatecznie przekonałem się, że właśnie Łesia Ukrainka jest jedną z najwybitniejszych ukraińskich autorek poetyckich utworów, przede wszystkim dramatycznych. Ta wybitna poetka i myślicielka o szerokich horyzontach łączy w swoich utworach antyczne, biblijne, ukraińskie, apokryficzne oraz folklorystyczne motywy, fabuly i tematy. Podobnie jak Chopin wywarła na mnie w dzieciństwie wyjątkowy wpływ. Byłem w klasie trzeciej, może czwartej, kiedy siostra uczyła się już w dziesiątej. Telewizja lwowska w tych czasach emitowała wiele filmów inspirowanych utworami pisarzy ukraińskich. To byl, rzecz jasna, dobry materiał dydaktyczny. Gdy usłyszałem w domu, że siostra będzie oglądać 
ekranizację utworu Łesi Ukrainki, ryzykownie ogłosiłem, że mam zamiar również poznać to arcydzieło (dodatkową motywacją była dla mnie późna pora emisji, gdy zazwyczaj już spałem). Rodzice nie sprzeciwiali się za bardzo. Z trudem utrzymałem otwarte powieki do zakończenia filmu, a wtedy stało się coś dziwnego. Rodzice zaczęli mnie pytać, czy to, co obejrzałem, spodobało mi się, co mogę powiedzieć o temacie utworu, jak mógłbym scharakteryzować jego protagonistów... Zacząłem odpowiadać i zauważyłem zdziwione spojrzenia całej rodziny. Spytałem, o co chodzi, dlaczego są tak zaskoczeni (przypuszczałem, że moją zdolnością heroicznego zwalczania senności). A oni wciąż o coś pytali. W pewnym momencie, po chwili milczenia ktoś spytał: „Czy często tak mówisz?”, "Jak?” - zapytałem zdziwiony. Wtedy ktoś zaczął naśladować moją frazę i usłyszałem, że mówię - oczywiście: nie znając tego terminu - jambem. Posłuchawszy przez ok. półtorej godziny wierszowanego tekstu poematu, zacząłem mówić wierszem. Po raz pierwszy w moim życiu zasmakowałem możliwości mówienia rytmicznego, wierszowego. Co prawda potrzebowałem jeszcze dobrej ćwierci wieku, by zrozumieć, że poezja nie jest po prostu wierszem, banalną umiejętnością układania zrytmizowanych sylab.

Zastanawiając się nad relacją między Łesią Ukrainką i Chopinem, zauważyłem wiele symptomów ich wspólnej, że tak powiem, „przestrzeni wewnętrznej”. Fryderyk, jak wiadomo, już jako siedmiolatek miał w dorobku kilka drobnych kompozycji, a pierwszy recital, składający się m.in. z autorskich utworów, wykonał w wieku ośmiu lat. W tym samym wieku Łesia napisała swój pierwszy wiersz Nadzieja. Może warto zauważyć, że Chopin urodził się 22 lutego, a Łarysa Kosacz - 25 lutego.

Jeszcze jako dziecko Łesia, która bardzo lubiła muzykę, poświęciła fortepianowi, „dawnemu dobremu koledze”, wiersz:

Мій Аавній Аруже!

Мушу я з тобою розстатися надовго...

Жаль мені! 3 тобою звикла я Аілитися журбою,

Вповідувать Аумки весемі і сумні. [Łesia 1975-1979, t. 2: 68] 
Przyjacielu stary!

Muszę się z tobą rozstać na długo...

Żal mi! Z tobą przywykłam dzielić się strapieniem,

Powierzać myśli smutne i wesołe ${ }^{2}$.

Olesja Cerkowniak-Horodecka w artykule Fryderyk Chopin w twórczości Łesi Ukrainki przypomniała, że poetka swobodnie czytała nuty nawet skomplikowanych utworów muzycznych. Jednak najbardziej lubiła muzykę Chopina [Cerkown'ak-Horodets'ka 2021]. Jako dowód na to autorka studium przytoczyła szereg cytatów z listów poetki, w których wzmiankowany jest kompozytor. Na przykład w liście do matki, Oleny Pcziłky, w 1880 roku Łesia prosiła o zgodę na zakup nut, m.in. trzech fortepianowych utworów Chopina, gdyż chciała się ich nauczyć.

W liście do Olhy Kobyljanśkiej (z 21 lipca 1899 roku) Łesia pisała: „Będę wam grać Schumana i Chopina, których Wy, zdaje się, bardzo lubicie, a także wiele pieśni ukraińskich we własnej transkrypcji, wolnej od kontrapunktu i wszystkiej teorii" [cyt. za: Butycz 1971: 478]. W innym liście do Kobylańskiej (z 30 stycznia 1900 roku) poetka oceniała wykonanie utworów Chopina przez różnych pianistów: „Chopina, według mnie, pianistka Jesypowa gra nie gorzej, a nawet lepiej, ale jeśli brać pod uwagę klasyków, to Reis[enauer] dysponuje prawdziwą siłą" [cyt. za: Butycz 1971: 478, 480]. Łesia posiadała zdolność wnikliwej analizy osobliwości utworów Chopina oraz wyrafinowany artystyczny gust.

Autorem rzec można klasycznej rozprawy, uznawanej za jedną z najlepszych, o psychologii twórczości Łesi Ukrainki jest neoklasycysta Mykoła Zerow, słynny ukraiński poeta, historyk i teoretyk literatury, a także tłumacz. Analizując muzyczno-dźwiękowe asocjacje w jej utworach, pisał:

Wydaje mi się, że w wyobraźni Łesi Ukrainki obraz nie dominował nad dźwiękiem i nie wyprzedzał go. Każde zjawisko znajdowało u niej odzwierciedlenie i jako obraz, i jako dźwięk. A dźwięk wywoływał efekty wizualne, melodia odtwarzała w pamięci obrazy. [Zerow 2003: 403; przel. - M.T.] 
We własnych utworach Łesi Ukrainki występują dwie wzmianki o Chopinie. Pierwsza w opowiadaniu Głośne struny:

W pokoju stało pianino, nad nim była półka z popiersiami Chopina i Beethovena, między wawrzynami w wazonie; stała też etażerka $\mathrm{z}$ nutami i druga - z książkami, przeważnie dzieł znakomitych poetów, w ozdobnych oprawach. Pokój wyglądał dość ubogo, ale miał w sobie coś oryginalnego i przyciągającego. Było w nim mnóstwo kwiatów, i to najbardziej dodawało mu oryginalności [Łesia 1975-1979, t. 7: 143].

Natomiast w opowiadaniu Miasto smutku rozbrzmiewa utwór Chopina: „Huki kaleczonego pianina - to gra szalona pianistka, jej twarz podobna do ikony bizantyńskiej, oczy patrzą poważnie i srogo w przestrzeń, gra Grande Polonaise” [Łesia 1975-1979, t. 7: 137].

Uchwytne echa Sonaty fortepianowej b-moll op. 35 brzmią w cyklu poetyckich utworów Łesi pt. Осінні сnіви (Jesienne śpiewy). Przytoczę tu tylko fragment cyklu, jeden utwór: Чи naм'smaєme, коли я говорила... (Czy pamiętacie, kiedy ja mówiłam...).

Чи пам'ятаєте, коли я говорима

Оті слова: „Якби мені знаття,

Коли я вмру, я б заповіт зробила,

Аби з музикою, що мюба за життя,

Мене ховали”. Тільки що зметіли

Слова ті з уст, як вже зАались на сміх:

„Ви б, може, й танцювать примусити хотіли

На ваших поминках приятемів своїх?"

I почамась бамачка погребова...

Ïї спогадувать, зАавацось би, не варт,

Та я їі спогадую Ао слова,

Бо розбудив в Ауші поважне щось той жарт.

Моя Ауша не буде „со святими”,

Не буде „вічна пам' ять” по мені,

Чужі мені пісні з словами тими

I Азвони сі, потвори міАяні.

Коми вже треба голосить по трупі, 
Нехай музика плаче, та без слів, І жаль, і сміх, і плач, і пісня вкупі То буде так, мов мебединий спів. А та юрба, що посумує вранці, Увечері нехай іде в танець.

Се Аивно вам - після погребу танці?

Звичайний то смутним пісням кінець!

Та що ж, нехай не зрушу я нічого, Зірвавшися в безодню забуття, Аби не ранила так смерть моя нікого, Як ранило мене моє життя.

30.11.1900. [Łesia 1975-1979, t. 1: 264]

Czy pamiętacie, kiedy wam mówiłam słowa te: „Gdybym wiedziała, kiedy umrę, spisałabym testament, żeby z muzyką, jaką za życia kochałam, mnie pochowali". Gdy tylko spadty Słowa te z ust, zaczęły budzić śmiech: „Może jeszcze chciałabyś przymusić do tańca Przyjaciół na twej pogrzebowej uczcie?”. I zaczęła się pogwarka cmentarna... Zdaje się, że to niewarte nawet wzmianki, ale pamiętam co do słowa, bo żart poważnie zabrzmiał w mojej duszy. Moja dusza nie będzie „między świętymi”, nie dla mnie „wieczna pamięć”, Obce mi pieśni z tymi słowami I dzwony, miedziane potwory. Jeżeli trzeba lamentować nad trupem, niech muzyka płacze, ale bez słów I żal, i śmiech, i płacz, i wspólna pieśń Będą jak łabędzi śpiew. A tłum, co rankiem był smutnym, Niechaj wieczorem idzie $\mathrm{w}$ taniec. To dziwne dla was - pląsy po pogrzebie? Zwykły to koniec smutnych piosenek, 
No cóż, niechaj już nic nie zdołam zmienić,

Zstąpiwszy w otchłań zapomnienia,

By nie raniła moja śmierć nikogo tak,

Jak to moje życie mnie zraniło.

Jak wiadomo, właśnie na pogrzebie Chopina na Père-Lachaise brzmiał Marche funèbre. Powstanie poetyckiego cyklu Łesi Ukrainki Jesienne śpiewy zbiega się z czasem zgonu jej drugiego męża Serhija Merżyńskiego, w marcu 1901 roku.

Tak oto wyglądają inspiracje Chopinowskie w twórczości Łesi Ukrainki, a także moje własne relacje ze spuścizną obojga tych wybitnych ludzi.

\section{Bibliografia}

Butycz Iwan (1971), Łesia Ukrajinka. Dokumjenty i materiali (1871-1970), Naukowa dumka, Kyjiv.

Cerkown'ak-Horodets'ka Olesja (2012), Fryderyk Chopin u tworczos'ci Lesi Ukrajinky, „Kyjiws'ki polonostyczni studiji”, t. 19, s. 201-205.

Łesia Ukrainka (1975-1979), Zibrannja tworiw u 12 tomach, t. 1-12, red. E.S. Szabliowskij (golowa), Naukova Dumka, Kyjiv.

SBB (2021), Memento z banalnym tryptykiem, [dostęp: 16 grudnia 2021], https://www.tekstowo.pl/piosenka,sbb,memento_z_banalnym_ tryptykiem.html.

Zerow Mykoła (2003), Łesia Ukrajinka: krytyczno-biobibliograficznyj narys, w: tegoż, Ukraïnske pismenstwo, Osnowi, Kyjiv.

Myroslav Trofymuk

Fryderyk Chopin and Lesya Ukrainka. Per Me

The key word of the essay is per me, as I present in it my own reminiscence from my childhood and youth, which was when I first came into contact with the works of two exceptional maestros: Frédéric Chopin and Lesya Ukrainka (the pen name of Larysa Kosach). Chopin created musical poetry, while Lesya - a rhythmic and melodic verbal poetry. The dialogue of the two authors sounds amazing, uncovering an optimistic apotheosis of survival and the trauma of loss - the states expressed in Chopin's Marche funèbre and by Lesya Ukrainka in her poetry cycle devoted to this composition. 
The temporarily mature understanding of per me in both these creations also resulted from the trauma caused by the loss of close relatives (first, the grandad at a very young age) and hence became the drive for discovering the content of art and the means of expression characteristic to various branches of art.

Keywords: Frédéric Chopin; Lesya Ukrainka (Larysa Petrivna Kosach); Marche funèbre (Piano Sonata No. 2 in B-flat minor, Op. 35); Чи пам'sтаєте, коли я говорила... (Do you remember when I said ...) - Lesya Ukrainka's cycle Осінні співи (Autumn songs).

Myroslav Trofymuk - doktor habilitowany, docent Lwowskiego Narodowego Uniwersytetu im. Iwana Franki, historyk literatury, leksykograf, neolatynista, tłumacz tekstów łacińskich, niemieckich, polskich, bloger i eseista. Laureat Nagrody im. Iwana Wyhowskiego (2017), członek Naukowego Towarzystwa im. Mychajła Hruszewskiego (нтш), Asocjacji Pisarzy Ukraińskich, Narodowego Związku Dziennikarzy Ukraińskich (Ансжу), Związku Badaczy Literatury Nowołacińskiej (IANLS), Polskiego Towarzystwa Filologicznego (PTF), niegdyś dyrektor i założyciel Instytutu Studiów Nowołacińskich Ukraińskiego Uniwersytetu Katolickiego (Lwów). Współautor Stownika łacińsko-ukraińskiego (dwie edycje: 2001, 2012). Autor wierszy i utworów prozaicznych: nowel oraz esejów. 